\title{
PENINGKATAN MUTU PENDIDIKAN MELALUI PERANAN SUPERVISI PENDIDIKAN OLEH GURU UNTUK MENUJU PERBAIKAN MENTAL,MANDIRI,PARTISIPATIF,EFISIEN DAN AKUNTABILITAS PESERTA DIDIK
}

\author{
Sri Wulandari \\ Email: sri45836@gmail.com
}

\begin{abstract}
Abstrak
Supervisi Pendidikan merupakan usaha yang diberikan untuk guru dalam membimbing peserta didik di sekolah agar lebih memiliki kemampuan skill yang tinggi baik di bidang akademik maupun dibidang non akademik.Melalui supervisi pendidikan memberikan pelatihan-pelatihan kepada guru bagaimana cara mendidik peserta didik agar lebih memiliki mental yang kuat,mampu mandiri dengan diri sendiri,memiliki akuntabilitas yang tinggi serta berpartisipasi didalam lingkungan baik disekolah,keluarga,maupun masyarakat sekitar.Melalui pelatihan-pelatihan yang diberikan kepada guru melalui supervisi pendidikan ini bisa meningkatkan motivasi guru didalam memberikan pengajaran karena telah dibekali ilmu atau cara-cara mengajar yang baik,membuat guru lebih inovatif didalam memberikan pengajaran serta memiliki strategi-strategi yang mumpuni didalam memberikan pengajaran materi kepada peserta didik sehingga dengan strategi yang dimiliki bisa membuat suasana di kelas lebih kondusif sehingga peserta didik dapat menangkap materi yang diberikan dengan cepat oleh guru.Pelatihan supervisi pendidikan yang diberikan kepada guru bisa meningkatkan budaya organisasi seorang guru didalam lingkungan sekolah,sehingga dengan budaya organisasi yang baik,terstruktur,terkodinir dengan guru bisa mencontohkan dengan peserta didik sehingga peserta didik memiliki ilmu tidak hanya akademik atau non akademik tetapi juga memiliki ilmu budaya organisasi yang baik dan benar dari guru.
\end{abstract}

Kata Kunci :Supervisi pendidikan,skill,mandiri,akuntabilitas,partisipatif peserta didik.pelatihan,budaya organisasi

\section{PENDAHULUAN}

\section{Latar Belakang Masalah}

Supervisi pendidikan berkembang seiring berkembangkan ilmu manajemen dikemukakan oleh Sabandi. (sabandi 2013) sedangkan supervisi menurut Suto Prabowo (2017:1) menunjuk kepada kegiatan pembinaan yang dilakukan kepala sekolah kepada guru untuk membantu perbaiki situasi pembelajaran agar para peserta didik dapat belajar lebih efektif dengan prestasi belajar yang meningkat.Kepala sekolah selaku pengkordinir seluruh kegiatan sekolah,mengupayakan semua guru untuk dapat berperan membantu pemerintah didalam meningkatkan mutu pendidikan dan pengajaran di sekolah.

Keberhasilan pelaksanaan supervisi pendidikan dalam rangka perbaikian 
mental,mandiri,partisipatif,efisien,dan akuntabilitas dari peserta didik dapat di ukur dari peningkatan belajar dari peserta didik tersebut.Penelitian Tenriningsih (2009) menemukan"terdapat hubungan langsung yang positif dan signifikan antara kinerja guru dengan prestasi belajar siswa dan terdapat hubungan langsung yang positif dan signifikan antara prestasi belajar siswa melalui supervisi pengajaran".Dimana disini kinerja guru yang semakin tinggi juga mempengaruh prestasi belajar siswa.

Dalam peningkatan mutu pendidikan melalui peranan supervisi pedidikan,guru harus bisa menguasai setiap karakter peserta didik sehingga bisa mengetahui kelebihan dan kekurangan yang dimiliki oleh setiap peserta didik,sehingga didalam proses belajar mengajar dapat berjalan dengan maksimal.

Berdasarkan uraian diatas,permasalahan dalam tulisan ini adalah (1).Apa SupervisiPendidikan?(2).Apasaja kegiatan supervisi pendidikan?(3).Bagaiamana cara guru dalam meningkatkan mutu pendidikan didalam supervisi pendidikan? Tujuan tulisan ini adalah 1.Mengetahui Supervisi Pendidikan, 2.Mengetahui kegiatan supervisi pendidikan, 3.Mengetahui cara guru dalam meningkatkan mutu pendidikan didalam supervisi pendidikan.

\section{PEMBAHASAN}

\section{Pengertian Supevisi Pendidikan}

Supervisi merupakan pengawasan terhadap pelaksanaan kegiatan teknis edukatif di sekolah, bukan sekedar pengawasan fisik terhadap fisik material.(Donni Juni Priansa 2005) sedangkan supervisi pendidikan menurut Bordman Et.Al.,(1953:5) adalah usaha menstimulir,mengkordinir,dan membimbing secara kontinyu pertumbuhan guru-guru disekolah baik secara individual maupun secara kolektif,agar lebih mengerti dan lebih efektif dalam mewujudkan seluruh fungsi pengajaran,dengan demikian mereka dapat menstimulir dan membimbing pertumbuhan setiap murid,sehingga demikian mereka mampu lebih cakap berpartisipasi dalam masyarakat modern.Artinya didalam supervisi pendidikan guru dituntut untuk lebih memperluas pemahaman tentang pembelajaran yang akan di berikan kepada peserta didik untuk meningkatkan kemapuan dari peserta didik tersebut sesuai dengan perkembangan zaman.

\section{Kegiatan Supervisi Pendidikan}

Kegiatan supervisi pendidikan dalam hal ini bermaksud meningkatkan mutu pendidikan bagi guru memperbaiki mental,mandiri,partisipatif,efisien,dan akuntabilitas peserta dalam hal untuk menjaga dan memelihara kualitas seorang guru dalam proses pembelajaran didalam kelas untuk menumbuhkan kualitas pendidik yang baik dan melahirkan generasi penerus yang memiiki skill yang tinggi.

\section{Cara guru dalam meningkatkan mutu pendidikan didalam supervisi pendidikan}

Dalam suatu lembaga pendidikan kepala sekolah sebagai pemimpinyang tertinggi bertanggung jawab penuh terhadap terlaksananya segala kegiatan yang dilaksanakan di lembaga pendidikan yang dipimpinnya, termasuk pelaksanaan efektivitas mengajar guru (Aksara 2017) .Kepala sekolah dituntut harus mampu mengembangkan wawasan dan bimbingan kerja sama dengan guru-guru serta 
mengawasi kurikulum, melakukan pengawasan terhadap kegiatan mengajar guru. Didalam meningkatkan mutu pendidikan didalam supervisi pendidikan yang harus dilakukan oleh seorang guru agar memiliki kemampuan yang tinggi adalah:

1.Mengikuti pelatihan.

Pendekatan peningkatan kualitas pembelajaran yang lebih efektif dapat dilakukan melalui peningkatan kompetensi guru yang dilakukan dengan pelatihan(sabandi 2013).Peningkatan pelatihan yang dilakukan oleh guru dapat meningkatkan kualitas pembelajaran yang lebih efektif.Menurut Mahapatro (2010:285) pelatihan adalah kegiatan yang diselenggarakan untuk meningkatkan pengetahuan dan keterampilan orang-orang untuk tujuan tertentu.

Menurut Stern \& Kemp (2004:126) alasan untuk dilakukan pelatihan untuk guru dalam meningkatkan kemampuan dalam mendidik siswa adalah:

a.Peningkatan kepuasaan kerja dan semangat guru

Melalui peningkatan kepuasaan kerja dan semangat guru ini dapat memeberikan kepuasaan tersendiri didalam diri seorang guru,sehingga denga memiliki kepuasan tersendiri seorang guru dapat mengaplikasikan ilmu nya kepada peserta didik.

b.Peningkatan motivasi guru

Melalui peningkatan motivasi diharapkan guru dapat memotivasi diri sendiri dan peserta didik.

c.Peningkatan inovasi dalam strategi dan hasil

Melalui pelatihan inovasi bisa membuat guru memiliki kreatifitas didalam pembelajaran yang akan diberikan kepada siswa.

d.Peningkatan dan proses dalam hasil yang maksimal

Melalui pelatihan ini diharapa guru dapat meningkatkan proses kedepannya agar lebih baik dari sebelummya.

e.Meningkatkan citra lembaga.

Melalui pelatihan ini seorang guru dapat meningkatkan eksistensi sekolah agar bisa memajukan mutu pendidikan yang baik kedepannya.

Dengan adanya pelatihan ini guru diharapkan dapat memberikan pengajaran yang baik dan efektif kepada peserta didik.

2.Menciptakan Budaya Organisasi Pembelajaran

Menciptakan budaya organisasi pembelajaran dapat memberikan peningkatan kualitas pembelajaran yang dilakukan oleh guru melalui budaya belajar dan mengetahui organisasi sehingga nantinya bisa menerapkan kepada peserta didik,sehingga peserta didik memiliki bekal organisasi yang baik,dan benar yang diberikan oleh guru sehingga di dunia pekerjaan kelaknya tidak mengalami kesulitan.

\section{PENUTUP}

\section{Kesimpulan}

Berdasarkan pembahasan diatas dapat disimpulkan bahwa supervisi pendidikan merupakan fungsi yang ditujukan untuk memperbaiki mutu pembelajaran yang dilakukan oleh guru secara secara sistematis dan berkelanjutan kepada peserta didik sehingga melalui peningkatan mutu supervisi pendidikan bisa menciptakan guru yang memiliki kualitas tinggi serta melahirkan peserta didik yang memiliki pengetahuan yang baik dan benar. 


\section{Saran}

Berdasarkan uraian diatas, maka disarankan guru harus mampu mengembangkan skill dan pengetahuan lebih profesional,untuk menunjang kreatifitas peserta didik supaya peserta didik dapat mengembangkan mental,jiwa partisipasif,mandiri,dan akuntabilitas didalam kehidupan sehari-hari.

\section{REFERENSI}

Aksara, A. Padanan. 2017. Dalam Upaya Peningkatan Profesionalisme Guru Pai Madrasah Di Kkmi Kecamatan Penjaringan.

Donni Juni Priansa. 2005. "Manajemen Supervisi \& Kepemimpinan Kepala Sekolah, (Bandung: Alfabeta ), h. 84 1." Manajemen Supervisi \& Kepemimpinan Kepala Sekolah 19-70.

Sabandi, Ahmad. 2013. "Supervisi Pendidikan Untuk Pengembangan Profesionalitas Guru Berkelanjutan Oleh: Ahmad Sabandi Universitas Negeri Padang." Pedagogi,Jurnal Ilmiah Ilmu Pendidikan Xiii(2):1-9. 